\title{
HARNÂME KİME SUNULMUŞTUR
}

\author{
MINE MENGi
}

15. yüzyılın ünlü șairi Şeyhî’nin Harnâme mesnevisi Türk edebiyatında hicviye tarzının başarılı örnekleri arasında yer alır. Eserin yazılış nedeni ve kime sunulduğu konusunda kaynaklarda verilen bilgiler ve ileri sürülen görüşler değişiktir.

Harnâme hakkında bilgi edinebildiğimiz en eski kaynaklar olan şuara tezkirelerinin konuyla ilgili söylediklerini iki grupta toplayabiliriz. Anadolu sahasında yazılmış en eski tezkireler olarak bilinen Sehî ${ }^{1}$ ve Latîfî́ ${ }^{2}$ Tezkirelerinin eserin yazılış nedeni konusunda verdikleri bilgi bir yere kadar ayndır. Her iki tezkire de Şeyhî'nin Harnâme'yi, bir diğer ünlü eserini, Hüsrev ü Şîrîn'i sunduğu kişiye yani II. Murad'a sunduğunu söyleyerek, mesnevinin sunulduğu devlet büyüğü üzerinde aynı görüşü paylaşırlar. Sehî ve Latîfî Tezkirelerinden sonra gene 16. yüzyılın biyografik eserleri arasında yer alan Âşık Çelebi ${ }^{3}$ ve Hasan Çelebi ${ }^{4}$ Tezkireleri ile Gelibolulu Âli'nin Künhü'l-Ahbâr'ında ${ }^{5}$ ise Harnâme'nin Çelebi Mehmed'e sunulduğu yazılıdır. Her üç eser de Harnâme'nin yazılı̧ nedenini, Şeyhî'nin kendisine Çelebi Mehmed tarafindan verilen Tokuzlar köyüne giderken, yolda, tımarın eski sahipleri tarafından uğradığı tecavüz olayına bağlarlar.

Daha yakun zamanlarda konuyla ilgili olarak yazılı söylenenlere baktığımız zaman, genellikle edebiyat tarihlerinin ve eser hakkında yapılmış kişisel çalışmaların Harnâme'nin yazılış nedenini Tokuzlar köyü olayına bağladıklarını ve eserin Çelebi Mehmed'e sunulduğu görüşü üzerinde birleştiklerini

\footnotetext{
1 Sehî, Heşt-Behişt, Istanbul 1325, s. 52-53.

2 Latîfi, Tezkiretü'ş-Şu'arâ Istanbul 1314, (ilâve kısmu) s. 216-217.

3 Âşık Çelebi, Meşâirü'ş-Şućarâ, London 1971, y. 254a.

4. Kınahzade Hasan Çelebi, Tezkire, Dil ve Tarih-Coğrafya Fak. Ktp. N. Aktunę yazmalan. No. 9, y. 170 b.

5 Gelibolulu Âli, Künhü'l-Ahbâr. Türk Tarih Kurumu Ktp. y. 45a.
} 
anlyyoruz'. Yalnızca Fuad Köprülü daha önce Harnâme'nin Çelebi Mehmed'e sunulduğu görüşünde olmasına rağmen ${ }^{2}$, daha sonra bu görüşten vaz geçerek eserin II. Murad'a sunulduğunu ileri sürmüştür³ ${ }^{3}$.

Şimdiye dek yazılanları bir kenara bırakarak konunun aydınlanmasına 1şık tutacak nitelikteki belgelere bakınca biz de Sehî ve Latîfî Tezkirelerinde söylendiği ve Köprülü'nün de bildirdiği gibi Harnâme'nin II. Murad'a sunulduğu görüşüne varıyoruz.

Her şeyden önce, elimizde bulunan Harnâme nüshalarından ${ }^{4}$ hiç birinde eserin Çelebi Mehmed'e sunulduğunu gösterir kayıda rastlamıyoruz. Buna karşılık hem Ali Emirî hem de Türk-İslâm Eserleri nüshasında ${ }^{5}$ Harnâme metininin içinde II. Murad'ın adı geçiyor. Her iki yazmanın müstensihi de "Der Medh-i Sultan Murad Han" başlığı altında

Maksad-1 dil murâd-1 cân-1 cihân

Şeh i Sultân Murâd Hân-1 zemân

beyitine yer vererek II. Murad'ı överler.

1 Köprülüzade Mehmed Fuad-Şahabeddin Süleyman, Yeni Osmanh Tarih-i Edebiyatı, Istanbul 1332, s. 153.

Türkçe Yazma Divanlar Kataloğu, I, Istanbul 1947, s. 19.

Tahir Olgun, Germiyanh Şeyhî ve Har-nâmesi, Giresun 1949, s. 9.

Faruk K. Demirtaş, Harnâme, Türk Dili ve Edebiyatı Dergisi, C. III, Istanbul 1949, s. $370-372$.

Faruk K. Timurtaş, Şeyhî'nin Harnâmesi Üzerinde Dil Araştırmalarn, Türk Kültürü Araştırmalan, I, sayı 2, Ankara 1964, s. 254.

Faruk K. Timurtaş, Şeyhî-Hayatı ve Eserleri, Istanbul 1968, s. 89 v.d.

Faruk K. Timurtaş, Şeyhî'nin Harnâme'si, Istanbul 1971, s. 5-9.

Nihad S. Banarl, Resimli Türk Edebiyatı Tarihi, fas. 6. Istanbul, s. 459.

2 M. Fuad Köprülü, Harnâme, Yeni Mecmua, 13, Istanbul 1917, s. 253-256.

3 M. Fuad Köprülü, Anadolu Türk dili ve edebiyatınn tekâmülüne umumî bir bakış XV. asır, Yeni Türk Mecmuası, I, say1 5, Istanbul 1933, s. 383, Divan Edebiyatı Antolojisi, s. 69 ; E. I., IV, s. 996.

4 Elde bulunan yazma Harnâme nüshaları şu kütüphanelerdedir:

a Bayezid Umumî Ktp., 5764, Divan içerisindedir.

b. Millet Ktp., Ali Emirî, manzum 238, Divan içerisindedir.

c. Millet Ktp., Ali Emirî, manzum 1016

d. Üniversite Ktp., T. Y. 2804, Divan içerisindedir.

e. Süleymaniye Ktp., Hacı Mahmud Ef. 3298, Divan içerisindedir.

e. Süleymaniye Ktp., Hacı Mahmud Ef. 3298, Divan içerisindedir.

f. Türk ve Islâm Eserleri Müzesi, 2010, Divan içerisindedir.

5 F. K. Timurtaş Türk ve İslâm Eserleri Müzesindeki Şeyhî Divanı nüshasında Harnâme' nin bulunmadığını söyler. Bkz. Şeyhĥ’nin Harnâme'si, Ist. 1971, s. 14. 
Sözünü ettiğimiz yazmalardan Ali Emirî nüshasının yazılı̧ tarihi 1438, Türk ve İslâm Eserleri Müzesindeki nüshanın yazılış tarihi ise 1447'dir. Şeyhî'nin ölüm tarihi kesinlikle bilinmemekle birlikte 1430'larda olduğu sanılmaktadır. Öyleyse adı geçen her iki nüshanın müstensihi de Şeyhî hayatta iken yaşamışlar hatta belki de şairle tanışmışlardır. Buradan Harnâme'nin kime sunulduğunu müstensihlerin bilme ihtimallerinin büyük olduğu kanısına varıyoruz. İstinsah tarihlerinin eski oluṣlarının yanı sura yazmaların her ikisi de güvenilir ve değerli yazmalardır. Ali Emirî nüshasının TDK tarafından tıpkıbasımı yapılmıştır. Türk ve İslâm Eserleri Müzesindeki nüshayı da Fuad Köprülü över ve güvenilir bir yazma olduğunu söyler ${ }^{1}$.

Ayrıca Harnâme'nin II. Murad'a sunulduğu düşüncesine bizi götüren bir başka neden daha vardır. Şeyhî’nin Divanında yer alan devlet büyüklerine sunduğu kasidelere bakacak olursak, şairin Çelebi Mehmed'e sunduğu kaside sayısının II. Murad'a sunduğu kaside sayısından daha az olduğunu görürüz. Şeyhî Çelebi Mehmed'e yalnızca bir kaside sunmuş, oysa II. Murad için birçok kaside yazmıştır. Anlaşılan Şeyhî'nin II. Murad'la ilişkisi Çelebi Mehmed'le olduğundan daha fazla olmuştur.

Sonuç olarak, yukarıda sözünü ettiğimiz yazılış tarihleri eski olan iki yazmada II. Murad'ı öven beytin bulunması, buna karşılık elde bulunan yazma Harnâme nüshalarının hiç birinde Çelebi Mehmed'in adına rastlanmaması, Şeyhî’nin II. Murad'a daha fazla sayıda kaside sunması, dolayısıyle şairin II. Murad'a daha yakın olduğu nedenlerine dayanarak Sehî, Latîfî ve Fuad Köprülü'nün görüşlerine katılıyor ve Şeyhî'nin Harnâme'sini II. Murad'a sunmuş olduğu ihtimalinin daha büyük olduğunu söylüyoruz.

1 Fuad Köprülü, Ahmedî mad. İ. A.

Başında Ahmedî Divanının yer aldığı Türk ve İslâm Eserleri nüshası 209 varaktır. Şeyhî Divanı 163a'dan başlar. Ahmedî Divanının bitimini gösteren satırlardan sonra Şeyhî Divanı yazmada başlıksız olarak yer alır. Harnâme, bir kısmı sahife kenarında olmak üzere Divanın sonunda bulunmaktadır. Şeyhî Divanunın sonunda müstensihin adı Şeyhî b. Şiblî es-Semerkandî olarak verilir. Yazma güzel bir talikle yazılmış olup. 851 Recebinde (12 Eylül 1447) tamamlanmiştur. 


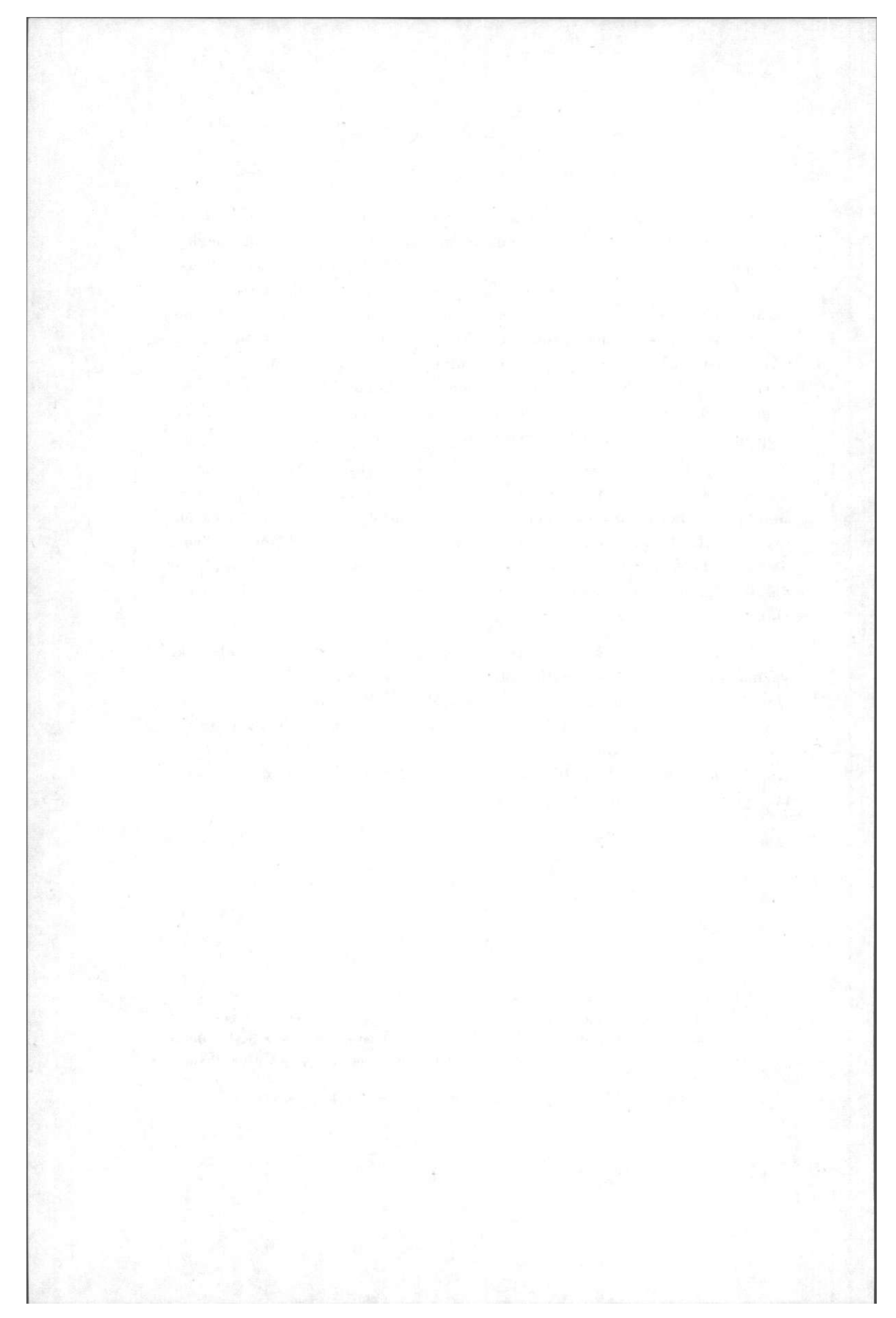

